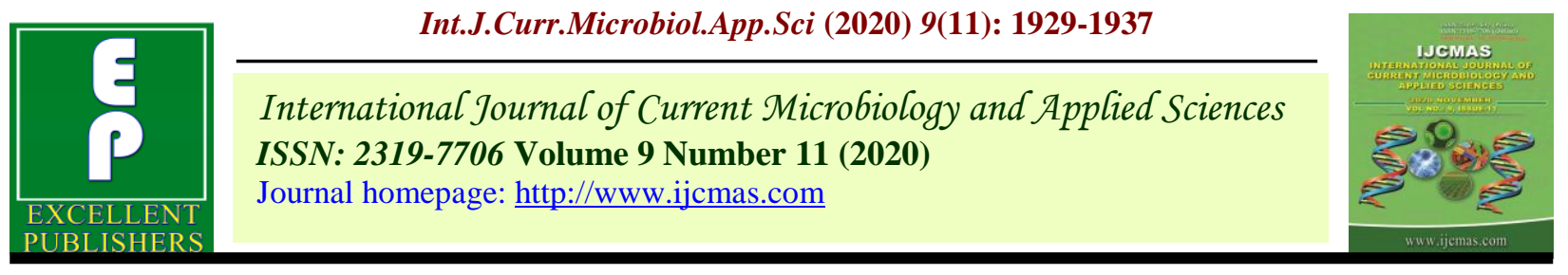

Original Research Article

https://doi.org/10.20546/ijcmas.2020.911.228

\title{
Effect of Variety, Levels of Fertilizer and Bio-fertilizer on Growth and Yield of Cumin (Cuminum cyminum L.)
}

\author{
Rutul Patel*, P. H. Patel, Sachin Desai and Jigar Joshi \\ Department of Agronomy, C. P. College of Agriculture, Sardarkrushinagar Dantiwada \\ Agricultural University, Sardarkrushinagar - 385 505, India \\ *Corresponding author
}

\begin{tabular}{l} 
Ke y w o r d s \\
Cumin, Variety, \\
$\begin{array}{l}\text { Fertilizer, } \\
\text { Bioferilizer, Seed } \\
\text { and straw yield }\end{array}$ \\
Article Info \\
\hline $\begin{array}{l}\text { Accepted: } \\
\text { 12 October } 2020 \\
\text { Available Online: } \\
10 \text { November } 2020\end{array}$ \\
\hline
\end{tabular}

Keywords

Cumin, Variety,

Fertilizer,

Bioferilizer, Seed

nd straw yield

Article Info

Accepted:

Available Online:

A B S T R A C T

A field experiment was conducted during rabi, 2017-18 on loamy sand soil at Agronomy Instructional Farm, C. P. College of Agriculture, Sardarkrushinagar Dantiwada Agricultural University, Sardarkrushinagar to evaluate the effect of variety, chemical fertilizer and bio-fertilizers on growth and yield of cumin. Twelve treatment combinations comprising of two varieties (GC 3 and GC 4), two levels of fertilizer (100\% and 50\% RDF) and three levels of biofertilizers (Azotobacter + PSB, Azospirillum + PSB and NPK consortium) were laid out in randomized block design (factorial) with four replications. Significantly higher growth attributes (plant height at harvest and number of branches/plant), yield attributes (number of umbels/plant, number of umbellates/umbel, number of seeds/umbellate, test weight and harvest index) and seed and straw yield $\left(\mathrm{kg} \mathrm{ha}^{-1}\right)$ were found when cumin variety GC 4 was fertilized with $100 \%$ RDF and inoculated with Azospirillum + PSB.

\section{Introduction}

Seed spices are known as an integral part of Indian culture that's why India is known as home of spices. The seed spices are annual herbs, whose dried seeds are known as spices and widely used in culinary, confectionary, perfumery, cosmetics and pharmaceutical industries. Cumin is extensively cultivated in India. Cumin aldehyde or cuminol is 36.31 per cent in cumin which attributes the specific value added aroma. It has carminative, stomatic, anti-diarrheal and dyspecial medicinal properties. Cumin occupies 47.0 per cent of total seed spices area but accounts for 35.7 per cent of total seed spices production in the country. Among different factors known to augment crop production, identification of new genotype having wider adaptability and responsiveness to input are 
considered essential for exploiting higher yield potential. The identification of such high yielding adaptable varieties as per crop growing situation is considered to be first and foremost step for development of production technology. This study will help in replacing older variety with newer one. It is an established fact that potential of the genotype is realised to the fullest extent when it is grown under optimum environment. Plant nutrients play specific and important role in growth and development of a plant. Adequate mineral fertilization is considered to be one of the most important pre-requisites in this respect. Nitrogen plays a key role in the synthesis of chlorophyll and amino acids, which contributes to the building units of protein and thus growth of plant. It also helps in early establishment of leaf area capable of photosynthesis and increased root development to enable more efficient use of water. Next to nitrogen, phosphorus is of paramount importance in crops for increasing yield. Phosphorus, apart from its role in root development and nodule formation, plays an important role in energy transfer in the living cell by means of high phosphate energy bonds ATP and ADP (Havlin et al., 2003). Therefore, there is need to workout optimum combination of nitrogen and phosphorous for cumin. In recent years the rise in price of chemical fertilizers, scarcity of organic manures and poor nutrient use efficiency has led to search some alternative source of nutrition.

Biofertilizers facilitate economizing fertilizer nutrient use through utilizing BNF system, solubilising less mobile nutrients from fixed components and recycling of nutrients from crop residues. It is evidently clear that application of biofertilizers enhances the accumulation of soil enzymes, which is directly reflected on soil fertility index. The proper use of biofertilizers to crop not only provides economic benefit to the farmers, but also helps to improve and to maintain soil fertility and sustainability in natural ecosystem.

\section{Materials and Methods}

The present investigation was conducted during the rabi season in 2017-18 at Agronomy Instructional Farm of Chimanbhai Patel College of Agriculture, Sardarkrushinagar Dantiwada Agricultural University, Sardarkrushinagar, Dantiwada. It is situated in the North Gujarat Agro-climatic Zone. The soil of research farm was loamy sand in texture, poor in fertility and water holding capacity, having $\mathrm{pH} 7.61$, EC 0.11 $\mathrm{dS} / \mathrm{m}$; low in organic carbon $(0.31 \%)$ and available $\mathrm{N}(136.56 \mathrm{~kg} / \mathrm{ha})$ and medium in available $\mathrm{P}_{2} \mathrm{O}_{5}(43.41 \mathrm{~kg} / \mathrm{ha})$ and $\mathrm{K}_{2} \mathrm{O}(253.02$ $\mathrm{kg} / \mathrm{ha}$ ). The experiment comprising of two varieties (GC 3 and GC 4) along with two levels of fertilizer (100\% RDF and $50 \%$ $\mathrm{RDF}$ ) and three levels of biofertilizers (Azotobacter + PSB, Azospirillum + PSB and NPK consortium) were applied in 12 different combinations (Table 1). The treatments were evaluated und randomized block design (factorial) with four replications. Seeds of cumin variety GC 3 and GC 4 were developed by Main Seed Spices Research Station, Jagudan. $\mathrm{N}$ and $\mathrm{P}_{2} \mathrm{O}_{5}$ applied through urea and DAP, respectively.

The seeds were inoculated with respective strains of Azotobacter, Azospirillum, PSB and NPK consortium @ $25 \mathrm{ml} / \mathrm{kg}$ seed according to the treatment procured from Department of Microbiology, Anand Agricultural University, Anand. The crop was raised as per standard recommended cultural practices. Cumin was sown on $8^{\text {th }}$ November with seed rate of $10 \mathrm{~kg}$ $\mathrm{ha}^{-1}$ at $30 \mathrm{~cm}$ line spacing by broadcasting and harvested in last week of February. The data recorded during the course of investigation were subjected to statistical analysis as per method of analysis of variance (Panse and Sukhatme, 1978). 


\section{Results and Discussion}

\section{Effect of variety}

Data presented in Table 2 indicated that different treatments had a significant influence on growth attributes, yield attributes and yield of cumin. Significantly higher plant height $(28.66 \mathrm{~cm})$ and number of branches/plant (7.79) were recorded with GC 4 as compared to GC 3 because it is a varietal character. Inherent characteristic of particular variety plays a vital role on growth and development of crop which might be responsible for plant growth in terms of plant height and number of branches/plant. These findings are in accordance with the results reported earlier by Singh et al., (2003), Anonymous (2010) and Sengupta et al., (2014) in fennel.

Variety GC 4 recorded significantly more yield attributes viz., number of umbels/plant (30.04), number of umbellate/umbel (5.79), number of seeds/umbellate (5.96), test weight (4.667 g), harvest index (37.92\%); seed yield (437 kg/ha) and straw yield (716 kg/ha) as compared to GC 3. The higher yield attributing characters recorded under GC 4 variety might be due to genetic potential of particular variety. Similar results were also observed by Singh et al., (2003), Anonymous (2010) and Sengupta et al., (2014) in fennel and Rawal et al., (2014) in cumin. Better vegetative and reproductive growth of GC 4 is attributed to inherent build up and thereby produced higher number of umbels/plant, umbellate/umbel, seeds/umbellate and test weight. These components play a vital role and showed significant positive correlation with seed yield. Results are in concurrence with those of reported earlier by Anonymous (2010) and Meena and Singh (2013) in fennel and Rawal et al., (2014) in cumin. The difference in yield at different locations might be due to the genotypic differences and ecological variations. Similar results were also reported by Phurailatpam et al., (2016) in coriander.

\section{Effect of levels of fertilizer}

Significantly higher plant height $(27.95 \mathrm{~cm})$ and number of branches/plant (7.67) were recorded with An application of $100 \%$ RDF as compared to $50 \%$ RDF because it is a varietal character. The significant rise in growth parameters noticed under higher fertilizer level may be ascribed to the greater uptake of nutrients by the plants favoring better cell division, elongation, amino acid and protein synthesis and it might have produced more plant height, number of branches and plant dry matter production compared to lower fertilizer level. Similar finding was reported by Kumar et al., (2015) in fenugreek.

An application of $100 \%$ RDF recorded significantly more yield attributes viz., number of umbels/plant (30.29), number of umbellate/umbel (5.54), number of seeds/umbellate (6.13), harvest index (37.19 $\%)$; seed yield (424 kg/ha) and straw yield $(714 \mathrm{~kg} / \mathrm{ha})$ as compared to $50 \% \mathrm{RDF}$. Nitrogen and phosphorus fertilization plays a vital role in improving nutritional status of plant in both vegetative and reproductive part. These improvements suggest greater availability of metabolites and nutrients synchronized to demand for growth and development of each reproductive structure. These findings are in accordance with the results of Kumar et al., (2009) in fenugreek. With increased supply of nitrogen, the process of tissue differentiation from somatic to reproductive meristemic activity and development of floral premordia might have increased, resulting in more yield attributing characters. The results are in close agreement with the findings reported by Bedse et al., (2013) in cumin. The application of $100 \%$ 
RDF probably ensured sufficient supply of nitrogen and phosphorus to plants for development of yield attributes, which ultimately resulted into higher seed and straw yield. These results confirm the findings of Jat et al., (2012) in green gram. Nitrogen availability depends more or less on phosphorus. Phosphorus enhanced the symbiotic nitrogen fixation in legumes and ultimately improves the uptake of nutrients. Our results are in conformity with those reported by Verma et al., (2014) in cowpea.

\section{Effect of levels of biofertilizer}

Significantly higher plant height $(28.12 \mathrm{~cm})$ and number of branches/plant (7.75) was recorded with an inoculation of Azospirillum + PSB. The growth regulators like NAA and cytokinnins released by biofertilizers might have resulted in breaking of apical dominance and accelerated higher number of branches. These findings are in accordance with the results of Gudadhe et al., (2005) in brown sarson.
An inoculation of Azospirillum + PSB recorded significantly more yield attributes viz., number of umbels/plant (30.50), number of umbellates/umbel (5.75) and number of seeds/umbellate (6.06); seed yield (433 kg/ha) and straw yield $(750 \mathrm{~kg} / \mathrm{ha})$. Significantly higher harvest index (37.19\%) was observed under inoculation of Azotobacter + PSB. The seed inoculation with bacterial mixtures provided more nutrition for the plants and the improvement in root uptake of both nitrogen and phosphorus as a balance result of mechanism of interaction between nitrogen fixing and phosphate solubilising bacteria, which ultimately contributed into higher yield and yield attributing characters. Similar results were observed by Aishwath et al., (2012) in coriander. The increase in seed yield might be attributed to the fixation of atmospheric nitrogen production of biologically active compounds like organic siderophores which regulate the availability of nutrients to the crop. The positive influences as recorded in yield contributing characters under these treatments were manifested in the seed yield. Similar findings were reported by Gudadhe et al., (2005) in brown sarson.

Table.1 Treatment details

\begin{tabular}{|c|}
\hline Varieties $(\mathrm{V})$ : \\
\hline$V_{1}=\mathbf{G C} 3$ \\
\hline$V_{2}=\mathbf{G C} 4$ \\
\hline Levels of fertilizer (F) : \\
\hline$F_{1}=100 \%$ RDF $\left(40: 15: 0, \mathrm{~N}: \mathrm{P}_{2} \mathrm{O}_{5}: \mathrm{K}_{2} \mathrm{O}, \mathrm{kg} / \mathrm{ha}\right)$ \\
\hline $\mathrm{F}_{2}=50 \%$ RDF (20:7.5:0, N:P $\left.\mathrm{P}_{2}: \mathrm{K}_{2} \mathrm{O}, \mathrm{kg} / \mathrm{ha}\right)$ \\
\hline Biofertilizers (B) : \\
\hline $\mathbf{B}_{1}=$ Azotobacter + PSB \\
\hline $\mathbf{B}_{2}=$ Azospirillum + PSB \\
\hline$B_{3}=$ NPK consortium \\
\hline
\end{tabular}


Table.2 Effect of variety, levels of fertilizer and biofertilizers on growth and yield of cumin

\begin{tabular}{|c|c|c|c|c|c|c|c|c|c|c|}
\hline \multicolumn{2}{|r|}{ Treatments } & $\begin{array}{c}\text { Plant } \\
\text { height at } \\
\text { harvest } \\
(\mathrm{cm})\end{array}$ & $\begin{array}{c}\text { Number } \\
\text { of } \\
\text { branches } \\
\text { /plant }\end{array}$ & $\begin{array}{c}\text { Number } \\
\text { of } \\
\text { umbels / } \\
\text { plant }\end{array}$ & $\begin{array}{c}\text { Number of } \\
\text { umbellates } \\
\text { / umbel }\end{array}$ & $\begin{array}{c}\text { Number } \\
\text { of seeds/ } \\
\text { umbellate }\end{array}$ & $\begin{array}{c}\text { Test } \\
\text { weight } \\
\text { (g) }\end{array}$ & $\begin{array}{c}\text { Seed } \\
\text { yield } \\
\text { (kg/ha) }\end{array}$ & $\begin{array}{c}\text { Straw } \\
\text { yield } \\
\text { (kg/ha) }\end{array}$ & $\begin{array}{c}\text { Harvest } \\
\text { index } \\
(\%)\end{array}$ \\
\hline \multicolumn{11}{|c|}{ Varieties (V) : } \\
\hline $\mathbf{V}_{1}$ & GC 3 & 25.26 & 6.58 & 27.83 & 4.79 & 5.29 & 4.205 & 356 & 640 & 35.72 \\
\hline $\mathbf{V}_{2}$ & GC 4 & 28.66 & 7.79 & 30.04 & 5.79 & 5.96 & 4.667 & 437 & 716 & 37.92 \\
\hline & S.Em. \pm & 0.44 & 0.18 & 0.60 & 0.15 & 0.60 & 0.138 & 12.1 & 21.1 & 12.1 \\
\hline & C.D. at $5 \%$ & 1.26 & 0.51 & 1.72 & 0.43 & 1.72 & 0.397 & 34.7 & 60.7 & 34.7 \\
\hline \multicolumn{11}{|c|}{ Levels of fertilizer (F) : } \\
\hline $\mathbf{F}_{1}$ & $100 \% \mathrm{RDF}$ & 27.95 & 7.67 & 30.29 & 5.54 & 6.13 & 4.634 & 424 & 714 & 37.19 \\
\hline $\mathbf{F}_{2}$ & $50 \% \mathrm{RDF}$ & 25.97 & 6.71 & 27.58 & 5.04 & 5.13 & 4.238 & 370 & 643 & 36.45 \\
\hline & S.Em. \pm & 0.44 & 0.18 & 0.60 & 0.15 & 0.60 & 0.138 & 12.1 & 21.1 & 12.1 \\
\hline & C.D. at $5 \%$ & 1.26 & 0.51 & 1.72 & 0.43 & 1.72 & NS & 34.7 & 60.7 & 34.7 \\
\hline \multicolumn{11}{|c|}{ Biofertilizers (B) : } \\
\hline $\mathbf{B}_{1}$ & : Azotobacter+ PSB & 27.03 & 7.13 & 29.00 & 5.25 & 5.50 & 4.467 & 395 & 657 & 37.44 \\
\hline $\mathbf{B}_{2}$ & $\begin{array}{c}\text { Azospirillum+ } \\
\text { PSB }\end{array}$ & 28.12 & 7.75 & 30.50 & 5.75 & 6.06 & 4.518 & 433 & 750 & 36.54 \\
\hline $\mathbf{B}_{3}$ & : NPK consortium & 25.72 & 6.69 & 27.31 & 4.88 & 5.31 & 4.323 & 362 & 628 & 36.47 \\
\hline & S.Em. \pm & 0.54 & 0.22 & 0.73 & 0.18 & 0.73 & 0.169 & 14.8 & 25.9 & 14.8 \\
\hline & C.D. at $5 \%$ & 1.55 & 0.63 & 2.11 & 0.53 & 2.11 & NS & 42.5 & 74.4 & 42.5 \\
\hline \multicolumn{11}{|c|}{ Interaction : } \\
\hline & $\mathbf{V} \times \mathbf{F}$ & NS & NS & NS & NS & NS & NS & NS & NS & NS \\
\hline & $\mathbf{V} \times \mathbf{B}$ & NS & NS & NS & NS & NS & NS & NS & NS & NS \\
\hline & $\mathbf{F} \times \mathbf{B}$ & NS & NS & Sig. & Sig. & NS & NS & Sig. & Sig. & Sig. \\
\hline & $\mathbf{V} \times \mathbf{F} \times \mathbf{B}$ & NS & NS & NS & NS & NS & NS & NS & NS & NS \\
\hline & C.V. \% & 8.0 & 12.1 & 10.1 & 13.9 & 13.0 & 17.2 & 14.9 & 15.2 & 1.6 \\
\hline
\end{tabular}


Table.3 Interaction effect of levels of fertilizer and biofertilizers on seed yield of cumin

\begin{tabular}{|c|c|c|}
\hline Treatments & $\begin{array}{c}\mathrm{F}_{1}: 100 \% \text { RDF }\left(40: 15: 00 \mathrm{~N}: \mathrm{P}_{2} \mathrm{O}_{5}: \mathrm{K}_{2} \mathrm{O}\right. \\
\mathrm{kg} / \mathrm{ha})\end{array}$ & $\begin{array}{c}\mathrm{F}_{2}: 50 \% \text { RDF (20:7.5:00 N:P } \\
\mathrm{kg} / \mathrm{ha})\end{array}$ \\
\hline $\mathrm{B}_{1}:$ Azotobacter+ PSB & 422 & 367 \\
\hline $\mathrm{B}_{2}:$ Azospirillum+ PSB & 493 & 373 \\
\hline$B_{3}:$ NPK consortium & 356 & 368 \\
\hline S.Em. \pm & \multicolumn{2}{|c|}{20.9} \\
\hline C.D. at $5 \%$ & \multicolumn{2}{|c|}{60.1} \\
\hline
\end{tabular}

Table.4 Interaction effect of levels of fertilizer and biofertilizers on straw yield of cumin

\begin{tabular}{|c|c|c|}
\hline Treatments & $\begin{array}{c}\mathrm{F}_{1}: 100 \% \text { RDF (40:15:00 N:P } \mathrm{P}_{2} \mathrm{O}_{5}: \mathrm{K}_{2} \mathrm{O} \\
\mathrm{kg} / \mathrm{ha})\end{array}$ & 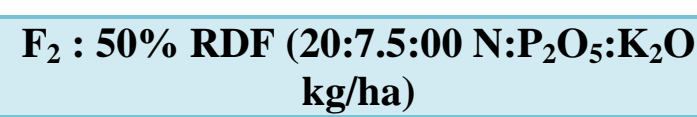 \\
\hline $\mathrm{B}_{1}:$ Azotobacter + PSB & 651 & 663 \\
\hline $\mathbf{B}_{2}:$ Azospirillum+ PSB & 851 & 648 \\
\hline$B_{3}:$ NPK consortium & 639 & 617 \\
\hline S.Em. \pm & \multicolumn{2}{|c|}{36.6} \\
\hline C.D. at $5 \%$ & \multicolumn{2}{|c|}{105.2} \\
\hline
\end{tabular}

Table.5 Interaction effect of levels of fertilizer and biofertilizers on harvest index of cumin

\begin{tabular}{|c|c|c|}
\hline Treatments & $\begin{array}{c}\mathrm{F}_{1}: 100 \% \text { RDF }\left(40: 15: 00 \mathrm{~N}: \mathrm{P}_{2} \mathrm{O}_{5}: \mathrm{K}_{2} \mathrm{O}\right. \\
\mathrm{kg} / \mathrm{ha})\end{array}$ & $\begin{array}{c}\mathrm{F}_{2}: 50 \% \text { RDF }\left(20: 7.5: 00 \mathrm{~N}: \mathrm{P}_{2} \mathrm{O}_{5}: \mathrm{K}_{2} \mathrm{O}\right. \\
\mathrm{kg} / \mathrm{ha})\end{array}$ \\
\hline B $_{1}$ : Azotobacter + PSB & 39.32 & 35.57 \\
\hline $\mathrm{B}_{2}:$ Azospirillum + PSB & 36.59 & 36.49 \\
\hline$B_{3}:$ NPK consortium & 35.66 & 37.29 \\
\hline S.Em. \pm & \multicolumn{2}{|c|}{0.21} \\
\hline C.D. at $5 \%$ & \multicolumn{2}{|c|}{0.61} \\
\hline
\end{tabular}




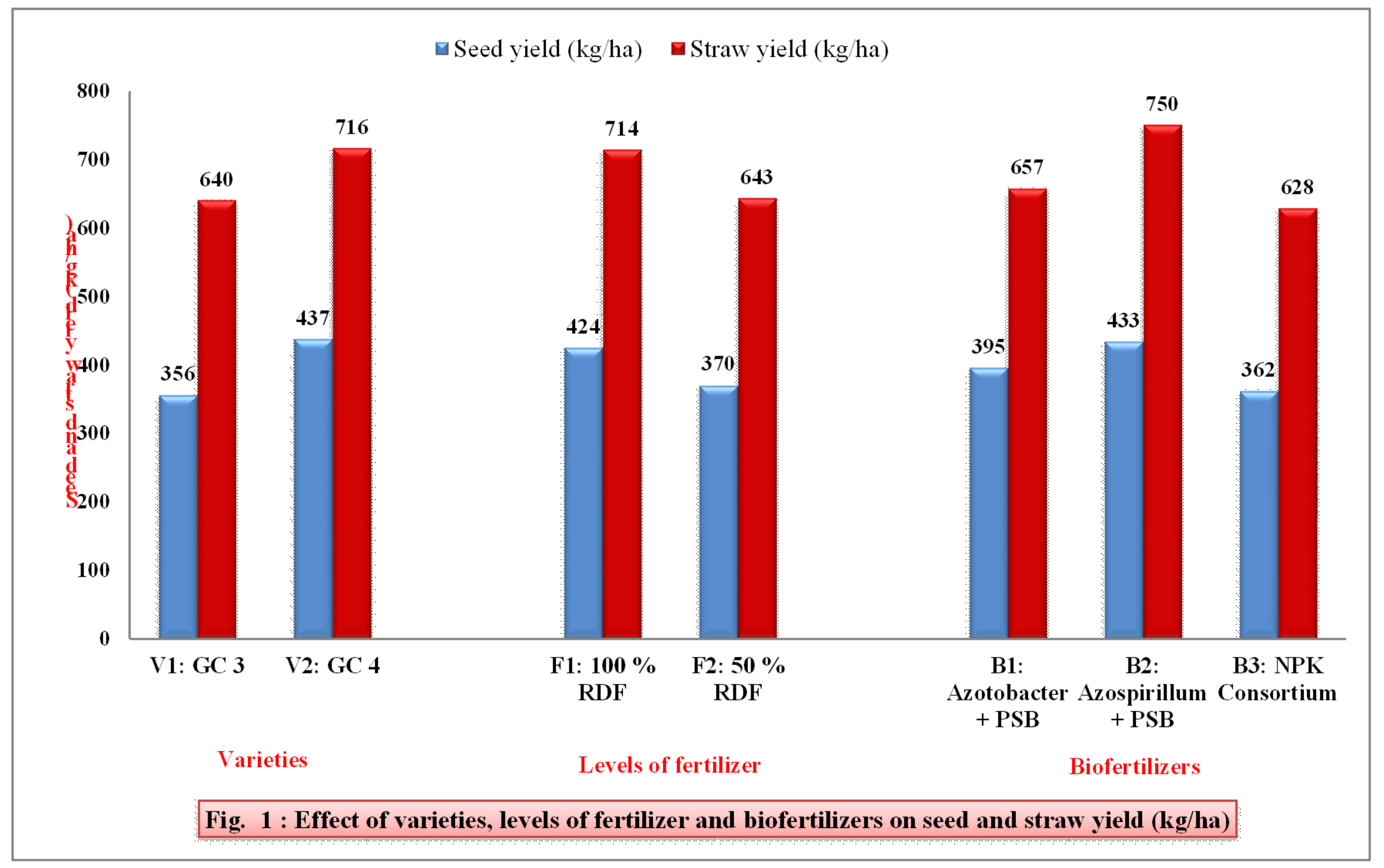




\section{Interaction effect}

Data presented in Table 3 and 4, Significantly higher seed yield (493 kg/ha) and straw yield $(851 \mathrm{~kg} / \mathrm{ha})$ were obtained under $100 \% \mathrm{RDF}$ and seeds inoculated with Azospirillum + PSB. The profound influence of nitrogen and phosphorus fertilization and inoculation with Rhizobium + PSB biofertilizers on biological yield mediated via increased photosynthetic efficiency and nutrient accumulation might have ultimately led to the production of higher yield under its application. The interactive advantages of combining fertility levels and bio-fertilizers generally proved superior. This might be due to synergistic effects of both and enhanced plant growth by promoting the merismatic activity, which favours plant growth and finally leaf and seed yield. Similar results were reported by Mehta et al., (2012) in fenugreek and Singh et al., (2012) in kasuri methi.

Significantly higher harvest index (39.32\%) was recorded under $100 \% \mathrm{RDF}$ and seeds inoculated with Azotobacter + PSB (Table 5). An application of $100 \%$ RDF with Rhizobium + PSB inoculation in combination under kasuri methi crop recorded significantly higher harvest index over control and rest of treatments. This is in close accordance with the findings of Singh et al., (2012) in kasuri methi and Mehta et al., (2012) in fenugreek.

In the view of the results obtained from the present investigation, it can be concluded that for securing higher seed yield from cumin (Cuminum cyminum L.) raised on loamy sand soil, the cumin variety GC 4 should be fertilized with 100\% RDF (i.e. 40:15:00 kg NPK/ha) along with seed inoculation with Azospirillum + PSB @ $25 \mathrm{ml} / \mathrm{kg}$ seed each.

\section{References}

Aishwath, O. P., Lal, G., Kant, K. and Sharma, Y. K., 2012. Influence of bio- fertilizers on growth and yield of coriander. International Journal of Seed Spices. 2 (2) : 9-14.

Anonymous, 2010. Annual Research Report of Seed Spices Research Station, Jagudan, Proposal for release of variety Gujarat Fennel 12 (GF 12) Submitted to the $39^{\text {th }}$ State Seed-committee, 2010, Sardarkrushinagar Dantiwada Agricultural University, Sardarkrushinagar. pp. 1-13.

Bedse, R. D., Amin, A. U., Raval, C. H. and Vaghela, S. J., 2013. Effect of rate and time of nitrogen application on growth, yield and economics of cumin (Cuminum cyminum L.) under loamy sand soil. An Asian Journal of Soil Science. 8 (1) : 45-47.

Gudadhe, N. N., Mankar, P. S., Khalwe, V. S. and Dongarkar, K. P., 2005. Effect of bio-fertilizers on growth and yield of mustard (Brassica juncea L.). Journal of Soils and Crops. 15 (1) : 160-162.

Havlin, J. L., Beaton, J. D., Tisdale, S. L. and Nelson, W. L., 2003. Soil fertility and fertilizers, $4^{\text {th }}$ Edition, Pearson Education (Singapore) Pvt. Ltd. Indian Branch, 482 FIE Patpargani, Delhi, India.

Jat, R. A., Arvadia, M. K., Tandel, B., Patel, T. U. and Mehta, R. S., 2012. Effect of land configuration, fertilizer rates and farm yard manure application on growth, yield and quality of greengram. Indian Journal of Agronomy. 57(3): 270-274.

Kumar, R., Meena, S. S., Kakani, R. K., Mehta, R. S. and Meena, N. K., 2015. Response of fertilizer levels and genotypes on productivity of fenugreek. International Journal of Seed Spices. 5 (1) : 63-67.

Kumar, S., Singh, D. and Nepalia, V., 2009. Performance of fenugreek (Trigonella foenum-graecum) varieties at various fertilizer levels and biofertilizer 
inoculations. Indian Journal of Agricultural Sciences. 79 (1) : 80-83.

Meena, M. L. and Singh, D., 2013. On-farm assessment of fennel varieties in Rajasthan. Journal of Spices and Aromatic crops. 22 (2): 200-202.

Mehta, R. S., Anwer, M. M., Aishwath, O. P. and Meena, R. S., 2012. Growth, yield and quality of fenugreek (Trigonella foenum-graecum L.) as influenced by nitrogen, phosphorus and bio-fertilizers. Indian Journal of Horticulture. 69 (1): 94-97.

Panse, V. G. and Sukhatme, P. V., 1967. Statistical methods for agricultural workers, ICAR Pub., New Delhi, p, 361.

Phurailatpam, A. K., Geetha, K. A., Meena, R. S. and Maiti, S., 2016. Evaluation of coriander cultivars for yield and yield contributing characters in Gujarat. Journal of Spices and Aromatic Crops. 25 (1): 7-12.

Rawal, R., Sharma, M., Srivastava, A., Thapa, R. B. and Khadka, R. B., 2014. Performance of cumin (Cuminum cyminum L.) varieties at different sowing dates. Nepal Agricultural Research Journal. 14: 53-58.

Sengupta, S. K., Verma, B. K. and Naidu, A. K., 2014. Genetic variability study in fennel (Foeniculum vulgare Mill.). International Science Journal. 1 (1): 6264.

Singh, S., Choudhary, M. R., Garhwal, O. P., Jakhar, M. L. and Yadav, B. L., 2012. Effect of biofertilizers and inorganic sources of nitrogen and phosphorus on quality production of kasuri methi (Trigonella corniculata). International Journal of Seed Spices. 2 (2) 38-40.

Singh, Y., Mittal, P. and Katoch, V., 2003. Evaluation of fennel genotypes under mid-hill humid sub-temperate conditions. Himachal Journal of Agricultural Research. 29 (1/2): 48-51.

Verma, H. P., Chovatiya, P. K., Dhikwal, S. R. and Regar, K. L., 2014. Effect of nitrogen and phosphorus levels on yields and economics of cowpea. Forage Research. 40 (3): 173-177.

\section{How to cite this article:}

Rutul Patel, P. H. Patel, Sachin Desai and Jigar Joshi. 2020. Effect of Variety, Levels of Fertilizer and Bio-fertilizer on Growth and Yield of Cumin (Cuminum cyminum L.). Int.J.Curr.Microbiol.App.Sci. 9(11): 1929-1937. doi: https://doi.org/10.20546/ijcmas.2020.911.228 